\title{
Data Terbaru Jenis-Jenis Belalang Sembah (Mantodea) di Desa Serdang Menang
}

\author{
Ari Sugiarto \\ Email: sugiartoari13@gmail.com
}

\begin{abstract}
Abstrak
Data belalang sembah (Mantodea) di Desa Serdang Menang pada tahun 2018 menunjukkan hanya terdapat 1 spesies yang ditemukan. Jumlah ini dinilai terlalu sendikit dan perkirakan masih ada spesies belalang sembah lainnya yang belum ditemukan pada penelitian sebelumnya, untuk itu diperlukan penelitan lanjutan mengenai jenis-jenis belalang sembah di Desa Serdang Menang dalam upaya melengkapi data penelitian sebelumnya. Hasil penelitian terbaru ditemukan 3 spesies belalang sembah yaitu Hierodula patellifera, Statilia maculata dan Tenodera sinensis yang termasuk dalam famili mantidae. Total 3 spesies yang didapat lebih mudah untuk ditemukan pada kawasan persawahan serta Hierodula patellifera dan Statilia maculata diperkiran populasinya lebih banyak dibanding Tenodera sinensis. Keberadaan belalang sembah di Desa Serdang Menang di harapkan dapat membantu dalam mengontrol populasi serangga yang bersifat merugikan.
\end{abstract}

Kata Kunci: Belalang sembah, Desa Serdang Menang

\section{Pendahuluan}

Data belalang sembah (Mantodea) di Desa Serdang Menang, Kecamatan Sirah Pulau Padang, Kabupaten Ogan Komering Ilir, Sumatera Selatan menunjukkan hanya satu spesies yang ditemukan (Sugiarto, 2018). Jumlah spesies yang ditemukan ini dinilai terlalu sedikit dan diperkirakan ada spesies belalang sembah lainnya di kawasan Desa Serdang Menang. Perkiraan ini berlandaskan bahwa Desa Serdang Menang termasuk dalam zona intertropical yang menurut Torres (2015), belalang sembah lebih banyak ditemukan di zona intertropical. Selain itu, jumlah spesies belalang sembah cukup banyak yang diperkirakan lebih dari 2.300 spesies (Zhang dan Fei, 2017). Hal inilah yang mendasari untuk dilakukannya penelitian ulang jenis-jenis belalang sembah di Desa Serdang Menang. Penelitian ini bertujuan untuk mengetahui jenis-jenis belalang sembah di Desa Serdang Menang terbaru guna melengkapai data penelitian yang telah dilakukan sebelumnya.

\section{Metode penelitian}

Penelitian ini dilakukan di Desa Serdang Menang, Kecamatan Sirah Pulau Padang, Kabupaten Ogan Komering Ilir, Sumatera Selatan pada November 2018 - Oktober 2019. Metode yang digunakan dalam penelitian ini sama dengan penelitian yang telah dilakukan oleh Sugiarto (2018) yaitu dengan mengikuti metode Dwari dan Amal (2018), Sampel dicari dengan sweeping area pada lokasi yang sudah ditentukan. Lokasi yang dipilih juga mengikuti Sugiarto (2018) yaitu sekitar kawasan ekosistem yang masih hijau (kawasan perkebunan, persawahan, dan tepian sungai). Sampel belalang sembah dikoleksi dengan menggunakan jaring serangga (Patel et al., 2018) dan juga di foto dengan menggunakan kamera ponsel. Sampel yang dapat dari jaring serangga di foto diatas kertas milimeter blok dan dilepaskan kembali setelah difoto untuk menjaga kelestariannya.

Indentifikasi sampel belalang sembah juga dilakukan dengan cara yang sama pada 
penelitian sebelumnya dengan cara mencocokan foto sampel belang sembah dengan foto spesies belalang sembah yang

\section{Hasil dan Pembahasan}

Total 3 spesies belalang sembah (Tabel 1) yang termasuk kedalam 3 genus dari famili Mantidae ditemukan di Desa Serdang Menang. Total 3 spesies belalang sembah yang ditemukan, Hierodula patillifera (Gambar 1a) dan Statilia sudah diidentifikasi. Perbedaan penelitian ini dengan penelitian sebelumnya hanya terletak pada lama waktu penelitan.

maculata (Gambar 1b) merupakan spesies belalang sembah yang lebih mudah untuk ditemukan di kawasan Desa Serdang Menang dibanding dengan Tenodera sinensi (Gambar 1c).

Tabel 1. Jenis-jenis belalang sembah (Mantodea) di Desa Serdang Menang

\begin{tabular}{ccc}
\hline No & Spesies & Nama umum \\
\hline 1 & Hierodula patellifera & Giant Asian mantis \\
2 & Statilia maculata & Asian jumping mantis \\
3 & Tenodera sinensis & Chinese mantis \\
\hline
\end{tabular}

Di kawasan persawahan lebih mudah untuk menemukan belalang sembah dibanding pada kawasan perkebunan dan tepian sungai, ini diperkirakatan terkait habitat dan ketersediaan makanan. Keberadaan belalang sembah pada kawasan perswahan tentunya dapat memberikan manfaat yang positif. Menurut Dwari dan Amal (2018), keberadaan belalang sembah pada ekosistem persawahan dan perkebunan dapat membantu dalam mengontrol populasi serangga yang berbahaya. Lebih lanjut Sureshan dan Sambath (2009) bahwa belalang sembah merupakan predator bagi belalang, ngengat, kupu-kupu, lalat dan kutu daun. Hal ini dinilai penting, sebab hasil penelitian Sugiarto (2018) menunjukkan jumlah spesies belalang antena penedek (Acrididae) cukup banyak banyak pada kawasan persawahan di Desa Serdang
Menang. Keberadaan belalang sembah pada kawasan persawahan diharapkan dapat mengontrol populasi dari belalang antena pendek yang cendrung berssifat merugikan terhadap tanaman, terutama padi. Menurut Dwari dan Amal (2018), belalang merupakan makanan favorit belalang sembah dari genus Hierodula dan Satilia.

Jumlah spesies belalang sembah yang ditemukan lebih banyak dibanding dengan penelitian yang dilakukan Sugiarto (2018) yang hanya menemukan Hierodula formosana. Indentifikasi Hierodula formosana yang ditemukan dinilai lebih mirip secara morfologi dengan Hierodula patellifera. Lama waktu penelitian dan penetapan lokasi sampling diperkirakan mempengaruhi jumlah spesies yang didapat. 


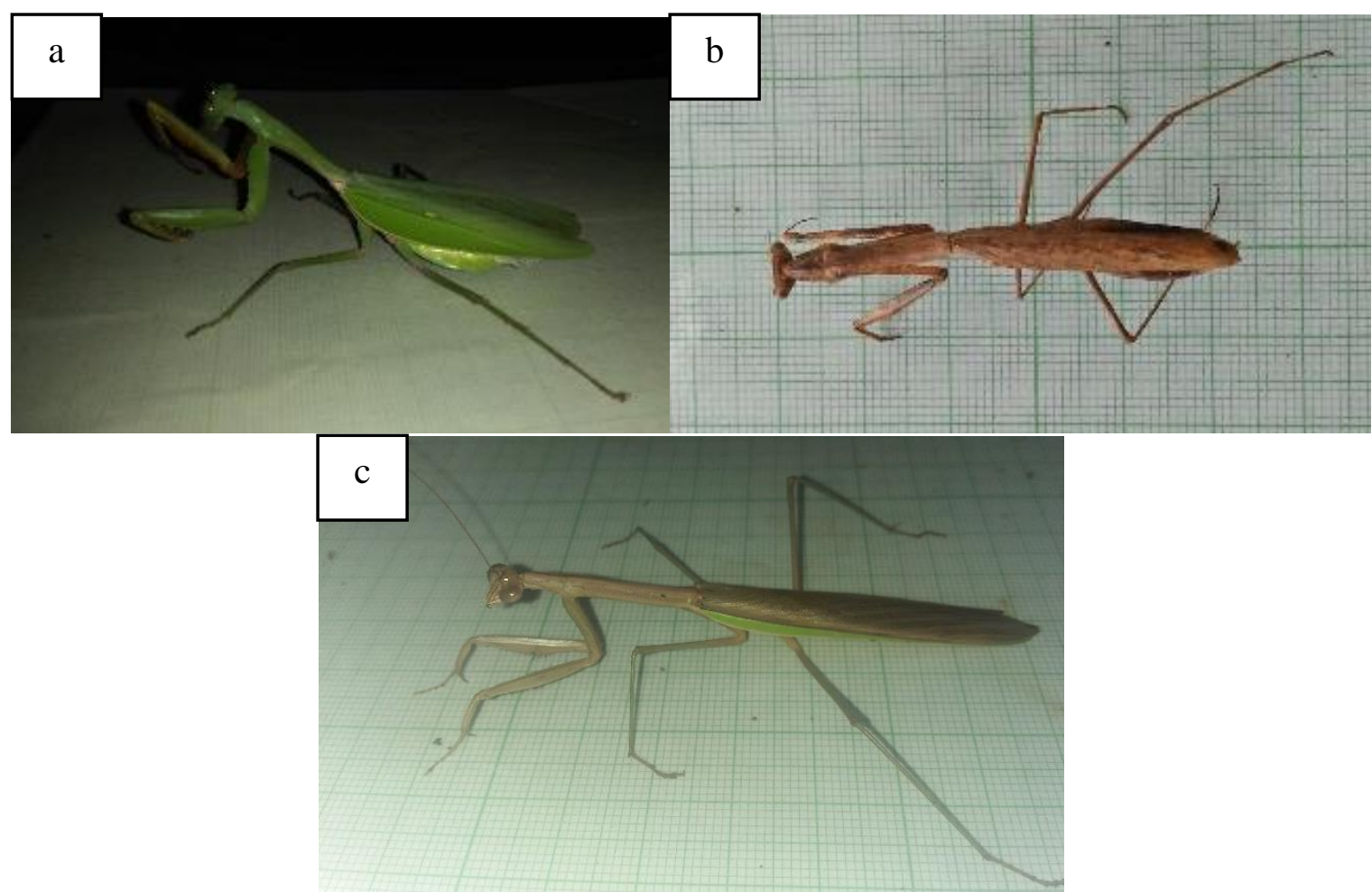

Gambar 1. (a) Hierodula patellifera, (b) Statilia maculata dan (c) Tenodera australasiae

\section{Kesimpulan}

Penelitian yang dilakukan menunjukkan Hierodula patellifera, Statilia maculata dan Tenodera sinensis merupakan spesies belalang sembah yang dapat ditemukan di Desa Serdang Menang terutama pada kawasan perswahan. Populasi Hierodula patellifera dan Statilia maculata diperkirakan lebih banyak dari pada populasi Tenodera sinensis, ini terlihat dari indikasi untuk lebih mudah menemukan Hierodula patellifera dan Statilia maculata dibanding Tenodera sinensis. Keberadaan sepesies belalang sembah di Desa Serdang Menang diharapkan dapat membantu dalam mengontrol populasi serangga yang bersifat merugikan.

\section{Daftar Pustaka}

Dwari, S dan Amal, K. M. 2018. Diversity of mantids (Insecta: Mantodea) of Howrah District, West Bengal, India. Journal of Entomology and Zoology Studies. 6(2): 1038-1042.

Patel, H. N., A. G, Shukla, A. H, Patel dan J. N, Prajapati. 2018. Mantids
(Mantodea) of Navsari Agricultural University Campus (Gujarat): An Inventory. International Journal of Current Microbiology and Applied Sciences. 7(6): 3594-3599.

Sugiarto, A. 2018. Inventarisasi Belalang (Orthoptera: Acrididae) di Perkebunan dan Persawahan Desa Serdang Menang, Kecamatan Sirah Pulau Padang, Kabupaten Ogan Komering Ilir. Kumpulan Artikel Insect Village. 1(3): 7-10.

Sugiarto, A. 2018. Inventarisasi Belalang Sembah (Mantodea) di Desa Serdang Menang, Kecamatan Sirah Pulau Padang, Kabupaten Ogan Komering Ilir. Kumpulan Artikel Insect Village. 1(2): 4-6.

Sureshan P. M dan Sambath S. 2009. Mantid (Insecta: Mantodea) Fauna of Old Bihar (Bihar and Jharkhand) with Some New Records for the 
State. Records of the Zoological Survey of India. 109(3):11-26.

Torres, F. P. 2015. Clase Insecta: Orden Mantodea. Revista. 1-10.
Zhang, H. L dan Fei, Y. 2017. Comparative Mitogenomic Analyses of Praying Mantises (Dictyoptera, Mantodea): Origin and Evolution of Unusual Intergenic Gaps. International Journal of Biological Sciences. 13(3): 367-382. 